OPEN ACCESS

Edited by: San-Gang Wu, First Affiliated Hospital of Xiamen University, China

Reviewed by:

Li Zhu,

Shanghai Jiao Tong University, China Qifeng Yang,

Shandong University, China

*Correspondence:

Yi Fang

fangyi@cicams.ac.cn

Zhihui Zhang

zhangzhh9@163.com

Jing Wang

wangjing@cicams.ac.cn

Specialty section:

This article was submitted to

Women's Cancer,

a section of the journal

Frontiers in Oncology

Received: 24 October 2020 Accepted: 01 February 2021

Published: 15 March 2021

Citation:

Zhang W, Fang Y, Zhang Z and

Wang J (2021) Management of Adenoid Cystic Carcinoma of the Breast: A Single-Institution Study.

Front. Oncol. 11:621012.

doi: 10.3389/fonc.2021.621012

\section{Management of Adenoid Cystic Carcinoma of the Breast: A Single-Institution Study}

\author{
Wenxiang Zhang ${ }^{1}$, Yi Fang ${ }^{1 *}$, Zhihui Zhang ${ }^{2 *}$ and Jing Wang ${ }^{1 *}$ \\ ${ }^{1}$ Department of Breast Surgical Oncology, National Cancer Center/National Clinical Research Center for Cancer/Cancer \\ Hospital, Chinese Academy of Medical Sciences and Peking Union Medical College, Beijing, China, ${ }^{2}$ Cytology Section \\ Department of Pathology, National Cancer Centre/National Clinical Research Center for Cancer/Cancer Hospital, Chinese \\ Academy of Medical Sciences and Peking Union Medical College, Beijing, China
}

Objective: The purpose of our study was to analyze the clinicopathologic features and surgical and oncological outcomes of adenoid cystic carcinoma (ACC) of the breast and to provide the basis for a clinical therapeutic schedule.

Methods: A total of 14 patients with primary breast adenoid cystic carcinoma treated at Cancer Hospital of the Chinese Academy of Medical Sciences from January 2000 to December 2017 were included. Data on clinical presentation, treatment strategy, and outcome, as well as the pathological features of ACC, were reviewed and analyzed.

Results: Fourteen patients were diagnosed with ACC of the breast, out of 23205 total patients treated for breast cancer (0.06\%). All but three patients were postmenopausal, with a median age at diagnosis of 60.5 years (range, 39-73 years). The most common clinical presentation was a palpable mass (85.7\%), and the imaging characteristics of all patients on color Doppler ultrasound and mammography were nonspecific. Six patients (42.9\%) were suspected of having ACC by fine-needle aspiration cytology (FNAC) and were confirmed by postoperative histology and immunohistochemistry. All 14 patients underwent surgery, and no patient had a positive lymph node status. Median tumor size was $1.75 \mathrm{~cm}$ (range, 1-3 cm). Eight/14 (57.1\%) patients were hormone receptor negative (HR-) and HER-2/neu (-) (HER2-). The remaining patients were hormone receptor positive $(\mathrm{HR}+)$. There was no significant difference in clinicopathological characteristics between the HR+ group and the HR- group (P>0.05). The mean follow-up period was 57 months. Local recurrence occurred in $14.3 \%$ of patients, $1.7 \%$ of patients had distant metastasis, all patients with local recurrence or distant metastasis were in the HR (-) group, and all patients were alive at the last follow-up.

Conclusion: ACC of the breast cannot be simply summarized as triple-negative breast cancer because it also includes a small number of hormone receptor-positive breast cancers. Establishing a preoperative diagnosis is difficult on the basis of clinical imaging examination, FNAC may be useful tool in the diagnosis. the final diagnosis can only be assessed based on the results of the histopathological and immunohistochemical examination. Breast-conserving surgery may be an alternative 
treatment strategy, and axillary lymph node dissection or sentinel node biopsy may not be necessary in some cases.

Keywords: adenoid cystic carcinoma, breast cancer, clinicopathological features, treatment, prognosis

\section{INTRODUCTION}

Adenoid cystic carcinoma (ACC) of the breast is a rare special histological type of breast cancer, accounting for approximately $0.1 \%$ of all breast tumors (1-3). Most cases are in females, and the median age of onset is between 50 and 60 years old $(4,5)$. However, occasional cases have been reported in male patients $(6,7)$. The typical clinical feature is a single mass of the breast, and multiple nodules are rare. Most ACCs are located under the areola or in the upper outer quadrants $(4,8,9)$. ACC of the breast has no characteristic imaging findings. Ultrasound features are those of a hypoechoic solid or heterogeneous mass. On mammography, the case may present as a lobulated mass with sharp or unsharp margins (8). Nevertheless, these clinical and radiographic features may be similar to any breast cancer, thus making their precise diagnosis difficult for radiologists (2).

Histologically, ACC of the breast typically consists of a dualcell population of luminal and myoepithelial-basal cells, which are generally negative for estrogen receptor (ER), progesterone receptor (PR), and human epidermal growth factor receptor 2 (HER2) $(2,10)$. However, the prognosis of ACC of the breast is usually better than that of other triple-negative breast cancers (4, 11). As prognosis is good, accurate preoperative diagnosis is important in the determination of suitable treatment. In addition, some studies have also reported some HR-positive ACC cases (5). The significance of a positive hormone receptor status is not known. Compared with ACC with negative HR expression, the clinical characteristics and prognosis of this type of ACC are also unknown.

One major obstacle when optimizing the therapeutic management of ACC is the rarity of the tumor. As a result, no consensus exists on the optimal therapy. This study presents the clinical manifestations, imaging characteristics, pathological findings, and surgical and oncological outcomes of breast ACC in patients seen at a single institution. At the same time, we assessed the utility of FNAC in the diagnosis of ACC of the breast. We also describe the clinicopathological features of HR+ ACC and compare them with those of HR- breast ACC. To the best of our knowledge, this study is one of the few that focuses on $\mathrm{ACC}$ with $\mathrm{HR}+$ status.

\section{MATERIALS AND METHODS}

From January 2000 to December 2017, a retrospective analysis revealed that 23,205 patients were diagnosed with breast cancer and surgically treated at XXX. Among these patients, a total of 14 patients were pathologically diagnosed with adenoid cystic carcinoma of the breast. We summarized the clinical and pathological data (age, sex, tumor size, tumor location, immunohistochemical features), management (surgical, chemotherapy, endocrine therapy, and radiation), estrogen and progesterone receptor status, and prognostic information of 14 patients with ACC and conducted statistical analysis.

In this study, ER status was determined by immuno histochemistry and defined as positive with a cut-off of $1 \%$. HER2 status was defined as positive if scored as $3+$ on immunohistochemistry or if fluorescence in situ hybridization demonstrated gene amplification. Three histological grades were determined according to WHO classification: Grade I, tumors with tubular and cribriform areas, but without solid components; grade II, cribriform tumors that were either pure or mixed with $<30 \%$ solid areas; and grade III, tumors with $>30 \%$ solid patterns.

Descriptive statistics are reported as frequencies and percentages. Differences between HR+ ACC and HR- ACC with regard to clinicopathological features were evaluated using the chi-square test, and $\mathrm{P}<0.05$ was considered statistically significant in all the analyses. All statistical analyses were performed using SPSS 26.0 software (IBM Corporation, Armonk, NY, USA). Overall survival was defined as the time from the first day of therapy to the date of death; if the patient was alive at the end of the follow-up period or was lost to followup, OS was censored on the last date the patient was known to be alive. Disease-free survival (DFS) was also calculated from the date of first diagnostic biopsy, with first recurrences, local or distant, being scored as an event, and with censoring of other patients at the time of last follow-up or death. DFS curves were drawn using Kaplan-Meier estimates and the curves were compared by the log-rank test. The study received approval from the Institutional Review Board of our institution, and patient consent was obtained.

\section{RESULTS}

\section{Clinical Features}

The study identified 14 out of 23,205 patients (incidence, $0.06 \%$ ) who underwent breast cancer surgery from January 2000 to December 2017. Table 1 lists clinical characteristics. All patients were female. Among the 14 patients, only three were premenopausal, and the remaining were postmenopausal. The median age of the diagnosis was 60.5 years, with a range of 39-73 years. There was no family history of breast cancer in any patients. The first symptom of all 14 patients was breast masses, of which one was accompanied by nipple discharge and one was accompanied by pain. The tumors were located in the right breast in nine cases and the left breast in five cases. The tumors located in the quadrant were eight cases in the upper outer quadrant, one case in the lower inner quadrant, two cases in the lower outer quadrant, and three cases in the central 
TABLE 1 | Baseline characteristics.

\begin{tabular}{lc}
\hline Characteristic & $\mathbf{n}=\mathbf{1 4}$ \\
\hline Incidence (\% of all breast cancer) & $0.06 \%$ \\
Mean age at diagnosis (range) & $60.5(39-73)$ \\
Female, $\mathbf{n}$ (\%) & $14(100)$ \\
Menopausal status, $\mathbf{n}(\%)$ & \\
Premenopausal & $3(21.4)$ \\
Postmenopausal & $11(78.6)$ \\
Laterality, $\mathbf{n}$ (\%) & \\
Left & $5(35.7)$ \\
Right & $9(64.3)$ \\
Tumor distribution, $\mathbf{n}(\%)$ & \\
Upper outer quadrant & $8(57.1)$ \\
Upper inner quadrant & $0(0)$ \\
Lower inner quadrant & $1(7.1)$ \\
Lower outer quadrant. & $2(14.3)$ \\
Central quadrants & $3(21.4)$ \\
Symptoms, $\mathbf{n}$ (\%) & $10(71.4)$ \\
Palpable mass & $1(7.1)$ \\
Palpable mass with pain & $1(7.1)$ \\
Palpable mass with nipple Discharge &
\end{tabular}

quadrants. Two tumors were found through routine screening, and 12 patients had found the tumor by themselves.

\section{Preoperative Examination}

Thirteen of the 14 patients underwent bilateral breast ultrasound. The mammogram was performed in five patients. Magnetic resonance imaging (MRI) of the breasts was performed in three patients. The imaging findings of ACC are summarized in Table 2. Tumors ranged in size from 0.6 to $2.81 \mathrm{~cm}$ with a median size of $1.6 \mathrm{~cm}$ on breast ultrasound. The sonographic characteristics of the ACC of the breast were all hypoechoic solids. Of the 13 patients who underwent breast ultrasound, 10 presented with an irregular mass. Mammograms were available for five of the 14 patients, and masses were identified in all cases. The tumor presented as an irregular or lobular mass with spiculated or indistinct margins. Small calcifications were found in one case. Only three patients underwent MRI, and all patients presented with an irregular mass. Compared with normal breast tissue, all lesions appeared homogeneously isointense on T1WI. After the injections of contrast agent, the enhancement of all masses was rapid and heterogeneous (patient 5) or rapid and homogenous (patient 10 and patient 11). On T2weighted imaging (T2WI), one patient (with a 2.06- $\mathrm{cm}$ mass) had extensive high T2WI signals and hypointense internal septations, which demonstrated plateau kinetics. In the other two cases with smaller lesions (with a $1.0-\mathrm{cm}$ mass), MRI showed that these lesions were isointense on T2 imaging; one mass demonstrated washout kinetics, and the other demonstrated plateau kinetics. Six patients underwent fine-needle aspiration cytology (FNAC), four underwent excisional biopsy, and four underwent core needle biopsy (CNB). Among the 6 cases of fineneedle aspiration, sieve-shaped epithelial cells were observed in five patients, and pieces of epithelial cells and mucoid globules were observed in one patient (Figure 1). In all cases, ACC was suspected. In postoperative histological sections, these cytological findings were compatible with the histological findings and were diagnosed as breast ACC. Only one patient was diagnosed with invasive breast cancer through the CBN, which had a biopsy in another hospital and did not undergo the immunohistochemical examination. The rest were diagnosed with ACC of the breast; microscopically, the tumor cells consisted of epithelial and myoepithelial cell types arranged into tubular or cribriform architecture.

\section{Pathological Findings}

All cases were diagnosed by two senior pathologists. Of the 14 patients, 13 had pure ACC, and one had ACC with ductal carcinoma in situ (DCIS). On histopathology, most tumors in our study formed by myoepithelial cells and glandular epithelial cells in a biphasic pattern which revealed a tubular subtype in three cases, a cribriform in 10 cases and a solid subtype in one case. Grade 1 was observed in nine of 14 cases (64.3\%), grade 2 in three of 14 cases $(21.4 \%)$ and grade 3 in one of $14(7.2 \%)$. The average maximum diameter of the tumor was $1.75 \mathrm{~cm}(1.0-$ $3.0 \mathrm{~cm}$ ). None of the cases had vascular tumor thrombus, and perineural invasion was present in three cases. The median number of lymph nodes examined was 5 (range, 1-29), and no patient had a positive lymph node status. In total, all patients had early-stage breast cancer (stages IA and IIA). Eight patients' ACCs were TNBC, while six patients were HR+/HER2-. Of the six ACCs that were HR+/HER2-, four cases were ER+ with $\mathrm{PR}+$, two cases were ER- with PR+. The Ki67 proliferation index was less than $14 \%$ in $71.4 \%$ of the cases analyzed for Ki67 (Table 3). Meanwhile, we compared the HR+ACC group with the HR+ACC group. A significant association between the two groups was not found in age, menopausal status, tumor size, clinical stage of surgical methods, KI67, progesterone receptor status, history of chemotherapy or radiotherapy $(\mathrm{P}>0.05)$. all information can be found in Table 4. As for immunohistological features, all patients were all CD117 (c-Kit) positive. immunohistochemical staining indicated CK5/6, p63 positive results in nine cases, 34-Beta-12 positive in two cases, S-100 in four cases, Calponin positive in four cases. The summary of all the findings is shown in Supplementary Table 1.

\section{Treatment and Prognosis}

All patients underwent surgery: four patients underwent radical mastectomy with axillary lymph node dissection (ALND), six patients underwent simple mastectomy with sentinel lymph node biopsy (SLNB), three patients underwent breastconserving surgery (BCS) with SLNB, and only one patient underwent wide local excision (WLE). Five of six patients with hormone receptor-positive tumors received hormonal therapy. Chemotherapy was performed in two patients. Of the four patients who underwent locoregional radiotherapy, all were in the BCS or WLE group (Table 5).

The median follow-up was 59 months (range 25-148 months). None of the patients had recurrence within the axilla. One patient (case 10) who experienced recurrence 11 months after the operation presented local recurrence again over the following 5 months and underwent two resections of chest wall recurrences while discovering lung metastases simultaneously in the second relapse. During disease progression, she was successively treated with doxorubicin/cyclophosphamide, 
TABLE 2 | Preoperative examination findings of patients with ACC of the breast.

\begin{tabular}{|c|c|c|c|c|c|c|c|c|c|c|c|c|}
\hline \multirow[t]{2}{*}{ Patient } & \multicolumn{4}{|c|}{ US findings } & \multicolumn{2}{|c|}{ Mammography findings } & \multicolumn{3}{|c|}{ MRI } & \multicolumn{3}{|c|}{ Preoperative pathological diagnosis } \\
\hline & $\begin{array}{r}\text { Size } \\
(\mathrm{cm})\end{array}$ & Boundary & $\begin{array}{l}\text { Internal } \\
\text { blood } \\
\text { vessel }\end{array}$ & Shape & $\begin{array}{l}\text { Size } \\
(\mathrm{cm})\end{array}$ & Features & $\begin{array}{l}\text { T2-weighted } \\
\text { signal } \\
\text { intensity }\end{array}$ & InternalEnhancement & Kinetics & $\begin{array}{l}\text { Diagnostic } \\
\text { method }\end{array}$ & Features & Conclusion \\
\hline 1 & 1.2 & Unclear & Yes & Irregular & 1.7 & $\begin{array}{l}\text { Irregular mass with indistinct } \\
\text { margins; No calcifications }\end{array}$ & None & None & None & FNAC & $\begin{array}{l}\text { Tubular and sieve- } \\
\text { shaped epithelial cells }\end{array}$ & $\begin{array}{l}\text { Suspected tubular cancer } \\
\text { or adenoid cystic } \\
\text { carcinoma }\end{array}$ \\
\hline 2 & 1.8 & Unclear & Yes & Irregular & Not done & Not done & None & None & None & FNAC & $\begin{array}{l}\text { Sieve-shaped epithelial } \\
\text { cells }\end{array}$ & Suspicious for ACC \\
\hline 3 & 1.9 & Unclear & Yes & $N R$ & 2.3 & $\begin{array}{l}\text { Irregular mass; No } \\
\text { calcifications }\end{array}$ & None & None & None & FNAC & $\begin{array}{l}\text { Sieve-shaped epithelial } \\
\text { cells }\end{array}$ & Suspicious for ACC \\
\hline 4 & 0.9 & Clear & Yes & Regular & Not done & Not done & None & None & None & FNAC & $\begin{array}{l}\text { Pieces of Epithelial } \\
\text { cells and mucoid } \\
\text { globules }\end{array}$ & Suspicious for ACC \\
\hline 5 & 2.06 & Unclear & Yes & Irregular & Not done & Not done & Hypointense & $\begin{array}{l}\text { Rapid and } \\
\text { heterogeneous }\end{array}$ & Plateau & CNB & None & Invasive carcinoma \\
\hline 6 & 1.8 & Unclear & No & Irregular & 1.8 & $\begin{array}{l}\text { Irregular mass with indistinct } \\
\text { margins, No calcifications }\end{array}$ & None & None & None & $\begin{array}{l}\text { Excisional } \\
\text { biopsy }\end{array}$ & $\begin{array}{l}\text { Tumor cells contain } \\
\text { mesh-like cyst-like } \\
\text { cavities }\end{array}$ & ACC \\
\hline 7 & 1.7 & Unclear & Yes & Irregular & Not done & Not done & None & None & None & CNB & $\begin{array}{l}\text { Tumor cells appear as } \\
\text { small tubes }\end{array}$ & ACC \\
\hline 8 & 1.1 & Unclear & Yes & Irregular & Not done & Not done & None & None & None & CNB & None & Suspicious for ACC \\
\hline 9 & 1.6 & Unclear & Yes & Irregular & 2.1 & $\begin{array}{l}\text { High-density nodule shadow; } \\
\text { Irregular shape; No } \\
\text { calcification }\end{array}$ & None & None & None & FNAC & $\begin{array}{l}\text { Sieve-shaped epithelial } \\
\text { cells }\end{array}$ & Suspicious for ACC \\
\hline 10 & 1 & Unclear & No & Irregular & Not done & Not done & Isointensity & $\begin{array}{l}\text { Rapid and } \\
\text { homogeneous }\end{array}$ & Washout & $\begin{array}{l}\text { Excisional } \\
\text { biopsy }\end{array}$ & $\begin{array}{l}\text { Tumor cells contain } \\
\text { mesh-like cyst-like } \\
\text { cavities }\end{array}$ & ACC \\
\hline 11 & 1 & Unclear & Yes & Irregular & Not found & Not done & Isointensity & $\begin{array}{l}\text { Rapid and } \\
\text { homogeneous }\end{array}$ & Plateau & CNB & $\begin{array}{l}\text { Tumor cells contain } \\
\text { mesh-like cyst-like } \\
\text { cavities }\end{array}$ & ACC \\
\hline 12 & 1.6 & Unclear & $\mathrm{NR}$ & Irregular & Not done & Not done & None & None & None & $\begin{array}{l}\text { Excisional } \\
\text { biopsy }\end{array}$ & $\begin{array}{l}\text { Tumor cells appear as } \\
\text { a cord }\end{array}$ & ACC \\
\hline 13 & $\begin{array}{l}\text { Not } \\
\text { done }\end{array}$ & Not done & Not done & $\begin{array}{l}\text { Not } \\
\text { done }\end{array}$ & Not done & Not done & None & None & None & $\begin{array}{l}\text { Excisional } \\
\text { biopsy }\end{array}$ & $\begin{array}{l}\text { Tumor cells contain } \\
\text { mesh-like cyst-like } \\
\text { cavities }\end{array}$ & ACC \\
\hline 14 & 2.81 & unclear & Yes & irregular & 3.2 & $\begin{array}{l}\text { Lobular mass with spiculated } \\
\text { margins; Small calcifications }\end{array}$ & None & None & None & FNAC & $\begin{array}{l}\text { Sieve-shaped epithelial } \\
\text { cells }\end{array}$ & ACC \\
\hline
\end{tabular}

FNAC, fine-needle aspiration cytology; CNB, core needle biopsy; ACC, adenoid cystic carcinoma. 

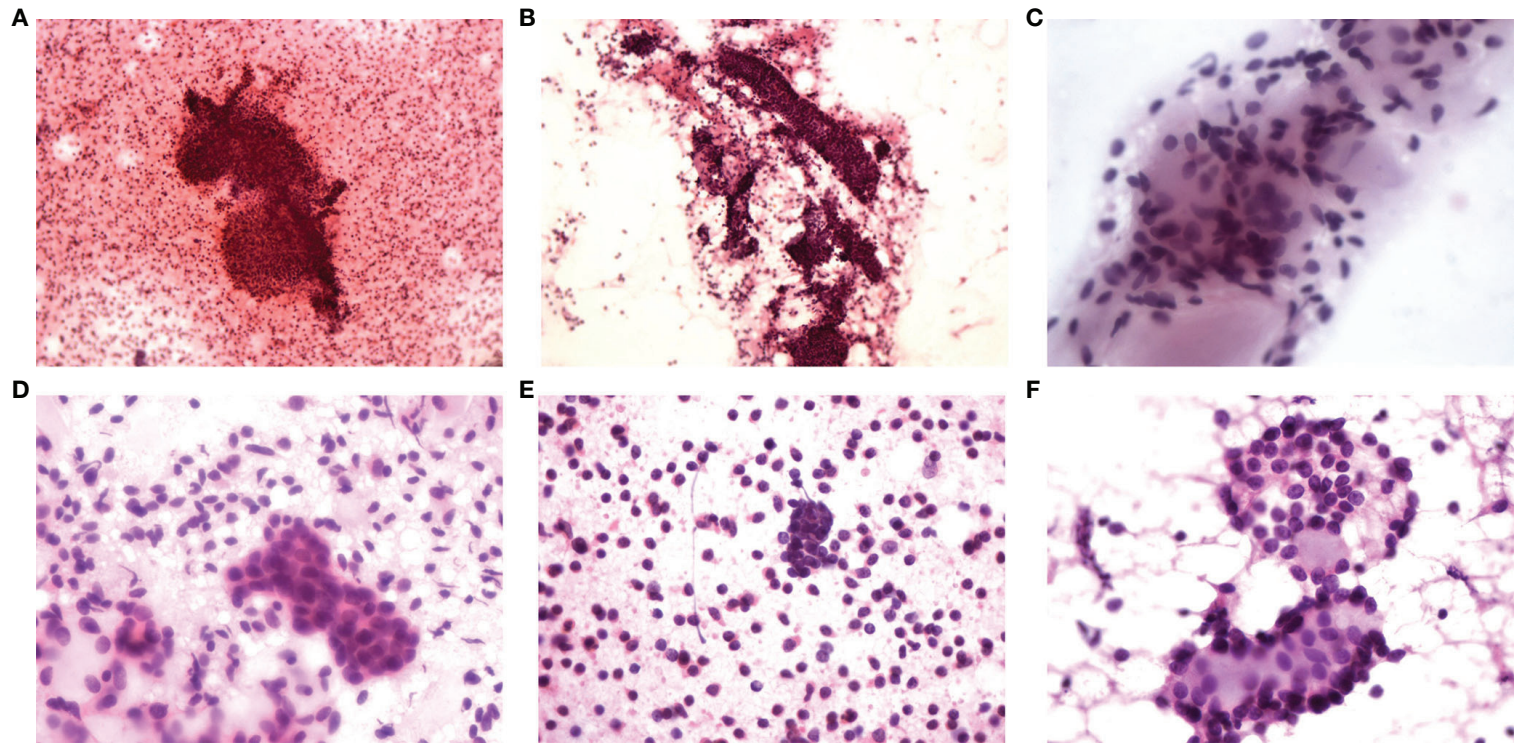

FIGURE 1 | FNAC findings of six cases. (A) Tubular and sieve-shaped epithelial cells; (B) Sieve-shaped epithelial cells; (C) Sieve-shaped epithelial cells; (D) Sieveshaped epithelial cells; (E) Pieces of epithelial cells and mucoid globules; (F) Sieve-shaped epithelial cells.

TABLE 3 | Pathologic characteristics of 14 patients diagnosed with ACC of the breast.

\begin{tabular}{|c|c|c|c|c|c|c|c|c|c|c|}
\hline Patient & $\begin{array}{c}\text { Tumor size } \\
\text { (cm) }\end{array}$ & $\begin{array}{l}\text { Histological } \\
\text { grade }\end{array}$ & $\begin{array}{c}\text { Tumor } \\
\text { Thrombus }\end{array}$ & $\begin{array}{c}\text { Perineural } \\
\text { invasion }\end{array}$ & $\begin{array}{c}\text { No. of resected } \\
\text { LNs }\end{array}$ & $\begin{array}{l}\text { Lymph node } \\
\text { metastasis }\end{array}$ & $\begin{array}{l}\text { TNM } \\
\text { stage }\end{array}$ & $\begin{array}{l}\text { Clinical } \\
\text { stage }\end{array}$ & $\begin{array}{c}\text { ER and PR } \\
\text { status }\end{array}$ & HER-2 \\
\hline 1 & 2.5 & Unknown & No & No & 29 & $\mathrm{pNO}$ & T2NOMO & Ila & ER-PR- & Negative \\
\hline 2 & 2.1 & 1 & No & No & 28 & pNO & T2NOMO & $\| \mathrm{a}$ & $\mathrm{ER}+\mathrm{PR}+$ & Negative \\
\hline 3 & 1.7 & 1 & No & No & 4 & pNO & T1CNOMO & la & ER-PR- & Negative \\
\hline 4 & 1.3 & 1 & No & No & 17 & pNO & T1CNOMO & la & $\mathrm{ER}+\mathrm{PR}+$ & Negative \\
\hline 5 & 2.2 & I & No & Yes & 7 & pNO & T2NOMO & Ila & ER+ PR- & Negative \\
\hline 6 & 1.8 & 1 & No & No & 4 & pNO & T1CNOMO & la & ER- PR- & Negative \\
\hline 7 & 2.2 & $\|$ & No & No & 3 & pNO & T2NOMO & Ila & ER- PR- & Negative \\
\hline 8 & 1.1 & 1 & No & No & 3 & pNO & T1cNOMO & la & $\mathrm{ER}+\mathrm{PR}-$ & Negative \\
\hline 9 & 1.7 & 1 & No & Yes & 4 & pNO & T1CNOMO & la & $\mathrm{ER}+\mathrm{PR}-$ & Negative \\
\hline 10 & 1 & III & No & No & 9 & pNO & T1bNOMO & la & ER- PR- & Negative \\
\hline 11 & 1.5 & $\|$ & No & No & 6 & pNO & T1CNOMO & la & $\mathrm{ER}+\mathrm{PR}-$ & Negative \\
\hline 12 & 1.6 & 1 & No & No & 5 & pNO & T1CNOMO & la & ER- PR- & Negative \\
\hline 13 & 2 & $\|$ & No & No & None & $\mathrm{CNO}$ & T1CNOMO & la & ER- PR- & Negative \\
\hline 14 & 3 & 1 & No & Yes & 1 & pNO & T2NOMO & Ila & ER- PR- & Negative \\
\hline
\end{tabular}

ER, estrogen receptor; PR, progesterone receptor; HER2, human epidermal growth factor receptor 2.

docetaxel/capecitabine/nituzumab, and gemcitabine/carboplatin. Fortunately, during our follow-up, this patient was still alive. The other patient had recurrence of the breast at 6 months after the operation, but after the second operation, she was lost to followup. Lapses occurred in the HR-ACC group. In all patients, the 5year DFS was 85.7\%, and Figure 2 shows the Kaplan-Meier survival curve.

\section{DISCUSSION}

Adenoid cystic carcinoma is a malignant tumor that occurs in the exocrine glands and in body parts with glands, including the salivary glands, lungs, prostate, and breasts (10). For breast ACC, a previous study using SEER data (1977-2006) showed that the age-adjusted incidence ratio (AAIR) of breast ACC is approximately 0.92 per 1 million person-years (11). In view of the rarity of this disease, there is a lack of understanding of the occurrence and development of the disease, and no consensus has been reached regarding clinical diagnosis and treatment. The current study reviewed 14 patients with breast ACC in a single institute during a 17-year period and analyzed the clinical presentations, imaging features, pathological characteristics and treatment outcomes. Demographically, the incidence of ACC of the breast was approximately $0.06 \%$ in this study. All patients were female, $85.7 \%$ of patients were postmenopausal, and the median age of diagnosis was 60.5 years. These characteristics are similar to those reported in previous studies $(11,12)$. 
TABLE 4 | Comparison of clinicopathological features of HR+ group and HRgroup.

\begin{tabular}{|c|c|c|c|c|}
\hline Characteristics & $\begin{array}{l}\text { HR-group } \\
\text { (n=8,\%) }\end{array}$ & $\begin{array}{c}\text { HR+ group } \\
(n=6, \%)\end{array}$ & $\begin{array}{c}\text { Total } \\
(n=14, \%)\end{array}$ & $P$ value \\
\hline \multicolumn{5}{|l|}{ Age (years) } \\
\hline$<60.5$ & $5(35.7)$ & 4 (28.6) & 9 (64.3) & \multirow[t]{2}{*}{0.872} \\
\hline$\geq 60.5$ & $3(21.4)$ & $2(14.3)$ & $5(35.7)$ & \\
\hline \multicolumn{5}{|l|}{ Year diagnosed } \\
\hline 2000-2015 & $5(35.7)$ & $2(14.3)$ & $7(50.0)$ & \multirow[t]{2}{*}{0.28} \\
\hline 2015-2017 & $3(21.4)$ & $4(28.6)$ & $7(50.0)$ & \\
\hline \multicolumn{5}{|l|}{ Menstrual status } \\
\hline Premenopausal & $1(7.1)$ & $2(14.3)$ & $3(21.4)$ & \multirow[t]{2}{*}{0.347} \\
\hline Postmenopausal & 7 (50.0) & $4(28.6)$ & $11(78.6)$ & \\
\hline \multicolumn{5}{|l|}{ Tumor size (cm) } \\
\hline$\leq 2 \mathrm{~cm}$ & $5(35.7)$ & $4(28.6)$ & 9 (64.3) & \multirow[t]{3}{*}{0.872} \\
\hline $2-5 \mathrm{~cm}$ & $3(21.4)$ & $2(14.3)$ & $5(35.7)$ & \\
\hline$>5 \mathrm{~cm}$ & $0(0)$ & $0(0)$ & $0(0)$ & \\
\hline \multicolumn{5}{|l|}{ Axillary staging } \\
\hline $\mathrm{N}_{\mathrm{O}}$ & $8(57.1)$ & $6(42.9)$ & $14(100)$ & $\mathrm{N} / \mathrm{A}$ \\
\hline \multicolumn{5}{|l|}{ Perineural invasion } \\
\hline Yes & $1(7.1)$ & $2(14.3)$ & $3(21.4)$ & \multirow[t]{2}{*}{0.347} \\
\hline NO & $7(50.0)$ & $4(28.6)$ & $11(78.6)$ & \\
\hline \multicolumn{5}{|l|}{ Ki 67} \\
\hline$\leq 14 \%$ & $7(50.0)$ & $3(21.4)$ & $10(71.4)$ & \multirow[t]{2}{*}{0.124} \\
\hline$>14 \%$ & $1(7.1)$ & $3(21.4)$ & $4(28.6)$ & \\
\hline \multicolumn{4}{|l|}{ Histological grade } & \multirow[t]{5}{*}{0.531} \\
\hline । & $4(28.6)$ & $5(35.7)$ & 9 (64.3) & \\
\hline$\|$ & $2(14.3)$ & $1(7.1)$ & $3(21.4)$ & \\
\hline III & $1(7.1)$ & $0(0)$ & $1(7.1)$ & \\
\hline Unknown & $1(7.1)$ & $0(0)$ & $1(7.1)$ & \\
\hline \multicolumn{5}{|l|}{ Surgical procedure } \\
\hline BCS or WLE & $2(14.3)$ & $2(14.3)$ & $4(28.6)$ & \multirow[t]{2}{*}{0.733} \\
\hline MT & $6(42.9)$ & $4(28.6)$ & $10(71.4)$ & \\
\hline \multicolumn{5}{|l|}{ Clinical stage } \\
\hline I & $5(35.7)$ & 4 (28.6) & $9(64.3)$ & \multirow[t]{2}{*}{0.266} \\
\hline$\|$ & $3(21.4)$ & $2(14.3)$ & $5(35.7)$ & \\
\hline \multicolumn{5}{|c|}{ Adjuvant radiotherapy } \\
\hline Yes & $2(14.3)$ & $2(14.3)$ & $4(28.6)$ & \multirow[t]{2}{*}{0.733} \\
\hline No & $6(42.9)$ & $4(28.6)$ & $10(71.4)$ & \\
\hline \multicolumn{5}{|c|}{ Adjuvant chemotherapy } \\
\hline Yes & $1(7.1)$ & $0(0.0)$ & $1(7.1)$ & \multirow[t]{2}{*}{0.369} \\
\hline No & $7(50.0)$ & $6(42.9)$ & $13(92.9)$ & \\
\hline \multicolumn{5}{|l|}{ Local recurrence } \\
\hline Yes & $2(14.3)$ & 0 & $2(14.3)$ & 0.186 \\
\hline No & $6(42.9)$ & $6(42.9)$ & $12(85.7)$ & \\
\hline Distant recurrence & & & & \\
\hline Yes & $1(7.1)$ & $0(0.0)$ & $1(7.1)$ & 0.369 \\
\hline No & $7(50.0)$ & $6(42.9)$ & $13(92.9)$ & \\
\hline
\end{tabular}

HR, hormone receptor; BCS, breast-conserving surgery; ALND, axillary lymph node dissection; SLNB, sentinel lymph node biopsy; MT, Mastectomy; WLE, wide local excision; N/A, not applicable.

The clinical presentation of breast ACC is nonspecific, making the diagnostic process challenging when only clinical features or imaging findings are available. The most common clinical presentation is a palpable mass (12-15). Other rare manifestations include breast pain, nipple discharge, and nipple retraction (14). Both sides can be affected, and most of them are located in the submastoid region or in the upper part of the outer quadrant (8). In this study, palpable masses accounted for $87.5 \%$, most of which were located in the upper part of the outer quadrant. One case was associated with nipple discharge, and the other was associated with breast pain. Imaging features of breast adenoid cystic carcinoma have been reported, however, Imaging characteristics are nonspecific and vary widely, resulting in relatively scarce information on the value of diagnosis and treatment through imaging features. Mammographically, these tumors may appear as irregular or lobulated mass with indistinct or spiculated margins (16). Sonographically, they appear hypoechoic and heterogeneous mass with unsharp margins (1), which is consistent with our study. In addition, the characteristics of MRI in adenoid cystic carcinoma of the breast are rarely reported and controversial. Tang W et al. (8) evaluated 11 patients' imaging examinations and found that a well-defined border, extensive high T2WI signals, and internal septations that demonstrate delayed enhancement in larger lesions, which are some valuable manifestations emerged on MRI, more interestingly, in their study, most patients showed benign lesions (four of nine had oval shapes, and seven of nine had smooth margins) on MRI. This is different from other studies, Glazebrook et al. (1) found that on MRI, the masses appeared as irregular shapes with spiculated margins. Kasagawa T et al. (16) described it as a round, oval, or irregular lesion with rapid enhancement (no wash-out) that extends from the margin to the center over time. In our study, only three patients underwent MRI. the masses showed irregular shapes, unenhanced scans showed that the mass of $2.06 \mathrm{~cm}$ demonstrated extensive hyperintensity on T2WI and that the mass of $1 \mathrm{~cm}$ demonstrated isointensity on T2WI, this information is similar to some results of Tang $\mathrm{W}$ et al. and Glazebrook et al. However, can these imaging features be the unique manifestations of adenoid cystic carcinoma of the breast, especially the imaging features on MRI, more analytical clinical studies are worthwhile in the future.

As one of the important methods for preoperative qualitative diagnosis of breast cancer, FNAC has a similar effect to pathological examination, and its diagnostic value has been generally recognized. However, for breast adenoid cystic carcinoma, only a few case reports or a small number of sample studies describe the application of FNAC in ACC diagnosis (6, 17-22). The diagnostic cytological findings of ACC are rarely described. There are only scattered descriptions, such as the cell smear having a single round circular hyperchromic cell, which exists in loose clusters, or the tumor cells surround the nucleus and sphere without cell homogeneous material $(21,22)$, so there is no uniform conclusion on the diagnostic value of FNAC in ACC. Quinodoz et al. (18) reported that immunocytochemistry may provide additional information on FNAC, which could be relevant not only for diagnosis but also for treatment and prognosis. Ilkay et al. (22) first reported a case of breast ACC that was diagnosed on the basis of immunohistochemical staining of FNAC cell block material. In our study, $42.9 \%$ of patients underwent FNAC before surgery. One of them needed to be differentiated from tubule cancer, and the others were highly suspected of ACC, all of which were confirmed histologically after surgery. Features of ACC in our study included cellular smear (uniform, round hyperchromatic cells) surrounded by epithelial cells with little cytoplasm and small hyperchromatic nuclei, from our experience, with these cytological characteristics, we can highly 
TABLE 5 | Treatment and prognosis of patients with ACC of the breast.

\begin{tabular}{|c|c|c|c|c|c|c|c|c|c|}
\hline Patient & Surgery & CT & RT & HT & Local Recurrence & DistantMetastasis & DFS (mo) & OS (mo) & Prognosis \\
\hline 1 & $\mathrm{MT}+\mathrm{ALND}$ & Yes & No & No & No & No & 115 & 115 & Alive \\
\hline 2 & $\mathrm{MT}+\mathrm{ALND}$ & No & No & Yes & No & No & 95 & 95 & Alive \\
\hline 3 & MT+SLNB & No & No & No & No & No & 95 & 95 & Alive \\
\hline 4 & $M T+A L N D$ & No & No & Yes & No & No & 83 & 83 & Alive \\
\hline 5 & $M T+A L N D$ & No & No & Yes & No & No & 59 & 59 & Alive \\
\hline 6 & $M T+S L N B$ & No & No & No & No & No & 64 & 64 & Alive \\
\hline 7 & MT+SLNB & No & No & No & No & No & 50 & 50 & Alive \\
\hline 8 & $\mathrm{BCS}+\mathrm{SLNB}$ & No & Yes & Yes & No & No & 34 & 34 & Alive \\
\hline 9 & MT+SLNB & No & No & No & No & No & 48 & 48 & Alive \\
\hline 10 & $\mathrm{MT}+\mathrm{SLNB}$ & Yes & No & No & Yes & Yes (lung) & 11 & 40 & Alive \\
\hline 11 & $\mathrm{BCS}+\mathrm{SLNB}$ & No & Yes & Yes & No & No & 32 & 32 & Alive \\
\hline 12 & BCS+SLNB & No & Yes & No & No & No & 25 & 25 & Alive \\
\hline 13 & WLE & No & Yes & No & Yes & Lapses & 6 & - & - \\
\hline 14 & MT+SLNB & No & No & No & No & No & 148 & 148 & Alive \\
\hline
\end{tabular}

CT, chemotherapy, RT, radiotherapy; HT, hormone therapy; DFS: disease-free survival; OS, overall survival; BCS, breast-conserving surgery; ALND, axillary lymph node dissection; SLND, sentinel lymph node biopsy; MT, Mastectomy; WLE, wide local excision.

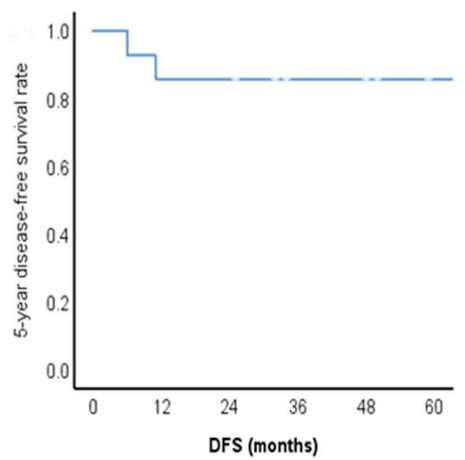

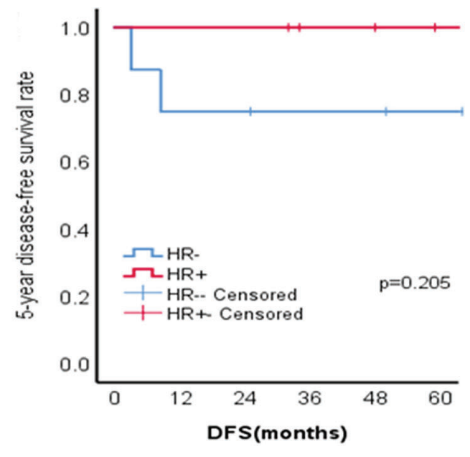

FIGURE 2 | Kaplan-Meier survival curves of patients with ACC of the breast. (A) 5-year disease-free survival (DFS) for 14 patients with ACC of the breast; (B) The 5year disease-free survival of HR + group and HR - group in patients with ACC of the breast $(p=0.205)$.

suspect ACC of the breast, if there is immunocytochemistry, this diagnosis is more convincing. Regrettably, cell block material or immunohistochemical staining was not performed on the tumor at the time, which may be part of the factor in the failure to truly diagnose ACC preoperatively.

Histologically, ACC of the breast has a biphasic pattern that consisted of true laminae and pseudo cystic spaces. True glands are lined by epithelial cells and pseudocysts are lined by myoepithelial cells, which are in various morphological configurations, including tubular, cribriform and solid patterns (23). The vast majority of studies show that the cribriform and solid histological patterns are the dominant patterns while a tubular pattern is less commonly. Previous studies found that cribriform and solid patterns were thought to predict more biological aggressiveness while tubular pattern represented a more differentiated pattern of ACC (24). Sequeiros et al. reported that patients with solid histological type had the worst prognosis, the cribriform type was in the middle, and the tubular type was the best (25). In our study, the main histological subtypes were the cribriform pattern in 10 patients (71.4\%), tubular pattern in three patients $(21.4 \%)$, and solid pattern in the remaining one patient $(7.1 \%)$. The histological subtype of patients with metastasis and recurrence are solid pattern and cribriform pattern. Furthermore, previously Scattered reports found these tumors are usually ER-negative and PR negative $(3,13,26)$. However, Arpino G et al. reported 28 patients and found that ER and PR expression were detected in $46 \%$ (13 of 28 ) and $36 \%$ (10 of 28 ) of ACC cases, respectively (27). In the current series of 14 cases, $28.5 \%$ were found to be ERpositive (four of 14) and $14.3 \%$ were PR positive (2 of 14). We compared the HR+ACC group with the HR+ACC group and found that there was no significant difference in clinicopathologic characteristics between the two groups, suggesting that perhaps a positive ER and PR status does not significantly affect the prognosis of the tumor. Because ACC of the breast is relatively rare, it is not realistic to develop standard treatment protocols through large-scale randomized clinical trials. Until now, the best treatment for ACC has remained 
controversial. In some early studies, most scholars recommended mastectomy as the initial treatment because of the low local recurrence rate $(28,29)$. However, in the context of comprehensive treatment, especially the application of radiotherapy technology, breast-conserving surgery (BCS) has become another choice for breast ACC $(27,30,31)$. In the study of Arpino et al., 6 patients (21.4\%) were treated by lumpectomy, and five patients received adjuvant RT after lumpectomy. all were no local recurrences (27). Khanfir K et al. (4) studied 61 patients with breast ACC and found that patients who had BCS + RT had significantly improved locoregional function compared to patients who had undergone BCS only ( $95 \%$ vs. $83 \%, \mathrm{p}=0.03$ ). There was no significant difference in the 5-year actuarial local control rate between $\mathrm{BCS}+\mathrm{RT}$ and mastectomy $(\mathrm{p}=0.16)$. Furthermore, a recent study using SEER data (1998-2011) evaluated the benefit of radiotherapy in patients with breast ACC and found that patients treated with lumpectomy + adjuvant RT had better survival rates than patients who underwent lumpectomy only (CSS, $\mathrm{p}=0.018$; OS, $\mathrm{p}=0.031$ ) or mastectomy only (CSS, p =0.010; OS, p =0.004) (12). which suggests that BCS and adjuvant RT may be the optimal local treatment procedure in patients with ACC of the breast (12). In our study, 4 patients (28.6\%) underwent breast-conserving surgery + local radiotherapy. Compared with the prognosis of patients with mastectomy, the results of this treatment showed similar outcomes. Although the proportion of this treatment mode seems to be relatively low, it is not difficult to find that all four patients were diagnosed and treated after 2015. In addition, with regard to the choice of local surgical treatment for ACC, doctors' preferences may also be mixed.

ACC of the breast has a very low rate of axillary lymph node metastasis. In a study using the California cancer registry, 5\% of patients had lymph node involvement (13). Even in other studies, none of the cases found axillary lymph node metastasis through sentinel lymph node biopsy or axillary lymph node dissection $(3,5)$. Thus, some studies recommend that axillary surgery might be omitted safely in patients with pure ACC and a clinically negative axilla. In our study, axillary operations were sentinel lymph node surgery in nine cases (64.3\%) and axillary lymph node dissection in four cases $(28.6 \%)$. All patients who completed axillary surgery $(n=13)$ were negative on the final pathology. This result suggests that our treatment of axillary lymph nodes may be excessive to some extent. In other words, axillary surgery might be omitted in patients in the future, but the choice of patients must be made cautiously. The value of systemic adjuvant chemotherapy for ACC of the breast has not been established. Systemic adjuvant chemotherapy can be considered for breast ACC patients with lymph node metastasis (greater than micrometastasis), tumor size $>3 \mathrm{~cm}$ or high lesion grade. Two of our patients received adjuvant chemotherapy, of which one patient had undergone MT+ ALND followed by systemic adjuvant chemotherapy. Another patient chose adjuvant chemotherapy due to local recurrence of the chest wall. However, we have no way to determine whether such systemic adjuvant chemotherapy can benefit survival due to the lack of a control and a small sample size.
Contrasted with other triple-negative, basal-like breast cancers and the ACC of the salivary gland, ACC of breast have a good prognosis. An increasing body of study has shown that the 5-year disease-free survival rate of breast ACC ranges from $82 \%-100 \%(4,27,30)$, and the 5-year overall survival rate was more than $80 \%(4,13,27,30)$. Macy $\mathrm{M}$ et al. reviewed related breast-ACC studies and found that Crude local recurrence and distant recurrence rates were $9.9 \%$ and $5.5 \%$, respectively, However, in their research, the unadjusted local and distant recurrence rate were $22.2 \%$ and $11.1 \%$, respectively (32). In our study, the crude local and distant recurrence rates were $14.3 \%$ and $7.1 \%$, respectively, at a median follow-up of 57 months. These uneven prognostic data suggest that ACC may not be a completely indolent TNBC subtype, which brings into question the best method of surveillance in these patients. Some studies have found that in the clinical course of ACC, the risk of secondary malignant tumors increases and that recurrence and metastasis will occur in the long term, so long-term follow-up is necessary.

\section{CONCLUSION}

In conclusion, our results show that the majority of ACCs were triple-negative, but our study also included a small number of hormone receptor-positive breast cancers. Compared with other types of breast cancer, ACC has no specificity in imaging, FNAC may be useful tool in the diagnosis. the final diagnosis can only be assessed based on the results of the histopathological and immunohistochemical examination. In our research, we found that BCS + RT may be the optimal local treatment for ACC. Such results need to be interpreted with caution because this was a single-center retrospective study, and the number of cases was small. In view of these limitations, the relevant conclusions should be further confirmed by larger scale studies.

\section{DATA AVAILABILITY STATEMENT}

The original contributions presented in the study are included in the article/Supplementary Material. Further inquiries can be directed to the corresponding authors.

\section{ETHICS STATEMENT}

The studies involving human participants were reviewed and approved by The authors are accountable for all aspects of the work in ensuring that questions related to the accuracy or integrity of any part of the work are appropriately investigated and resolved. This study has been approved by ethical review by the ethics committee of Cancer Hospital Chinese Academy of Medical Sciences. All procedures performed in studies involving human participants were in accordance with the ethical standards of the institutional and/or national research 
committee(s) and with the Helsinki Declaration (as revised in 2013). All subjects gave written informed consent in accordance with the Declaration of Helsinki. The patients/participants provided their written informed consent to participate in this study.

\section{AUTHOR CONTRIBUTIONS}

YF and JW contributed to the conception and design of the study. WZ wrote the first draft of the manuscript. ZZ performed the pathological investigation. All authors contributed to the article and approved the submitted version.

\section{REFERENCES}

1. Glazebrook KN, Reynolds C, Smith RL, Gimenez EI, Boughey JC. Adenoid cystic carcinoma of the breast. AJR Am J Roentgenol (2010) 194(5):1391-6. doi: 10.2214/AJR.09.3545

2. Miyai K, Schwartz MR, Divatia MK, Anton RC, Park YW, Ayala AG, et al. Adenoid cystic carcinoma of breast: Recent advances. World J Clin cases (2014) 2(12):732-41. doi: 10.12998/wjcc.v2.i12.732

3. Treitl D, Radkani P, Rizer M, El Hussein S, Paramo JC, Mesko TW. Adenoid cystic carcinoma of the breast, 20 years of experience in a single center with review of literature. Breast Cancer (2018) 25(1):28-33. doi: 10.1007/s12282017-0780-1

4. Khanfir K, Kallel A, Villette S, Belkacemi Y, Vautravers C, Nguyen T, et al. Management of adenoid cystic carcinoma of the breast: a Rare Cancer Network study. Int J Radiat Oncol Biol Phys (2012) 82(5):2118-24. doi: 10.1016/j.ijrobp.2010.12.008

5. Welsh JL, Keeney MG, Hoskin TL, Glazebrook KN, Boughey JC, Shah SS, et al. Is axillary surgery beneficial for patients with adenoid cystic carcinoma of the breast? J Surg Oncol (2017) 116(6):690-5. doi: 10.1002/jso.24702

6. Kshirsagar AY, Wader JV, Langade YB, Jadhav KP, Zaware SU, Shekhar N. Adenoid cystic carcinoma of the male breast. Int Surg (2006) 91(4):234-6.

7. Pang W, Wang Z, Jin X, Zhang Q. Adenoid cystic carcinoma of the breast in a male: A case report. Med (Baltimore) (2019) 98(32):e16760. doi: 10.1097/ MD.0000000000016760

8. Tang W, Peng WJ, Gu YJ, Zhu H, Jiang TT, Li C. Imaging Manifestation of Adenoid Cystic Carcinoma of the Breast. J Comput Assist Tomogr (2015) 39 (4):523-30. doi: 10.1097/RCT.0000000000000236

9. Torrao MM, da Costa JM, Ferreira E, da Silva MV, Paiva I, Lopes C. Adenoid cystic carcinoma of the breast. Breast J (2007) 13(2):206. doi: 10.1111/j.15244741.2007.00406.x

10. Marchio C, Weigelt B, Reis-Filho JS. Adenoid cystic carcinomas of the breast and salivary glands (or 'The strange case of Dr Jekyll and Mr Hyde' of exocrine gland carcinomas). J Clin Pathol (2010) 63(3):220-8. doi: 10.1136/ jcp.2009.073908

11. Ghabach B, Anderson WF, Curtis RE, Huycke MM, Lavigne JA, Dores GM. Adenoid cystic carcinoma of the breast in the United States (1977 to 2006): a population-based cohort study. Breast Cancer Res (2010) 12(4):R54. doi: $10.1186 /$ bcr2613

12. Coates JM, Martinez SR, Bold RJ, Chen SL. Adjuvant radiation therapy is associated with improved survival for adenoid cystic carcinoma of the breast. J Surg Oncol (2010) 102(4):342-7. doi: 10.1002/jso.21638

13. Kulkarni N, Pezzi CM, Greif JM, Suzanne Klimberg V, Bailey L, Korourian S, et al. Rare breast cancer: 933 adenoid cystic carcinomas from the National Cancer Data Base. Ann Surg Oncol (2013) 20(7):2236-41. doi: 10.1245/ s10434-013-2911-z

14. Kim M, Lee DW, Im J, Suh KJ, Keam B, Moon HG, et al. Adenoid cystic carcinoma of the breast: a case series of six patients and literature review. Cancer Res Treat (2014) 46(1):93-7. doi: 10.4143/crt.2014.46.1.93

15. Thomas DN, Asarian A, Xiao P. Adenoid cystic carcinoma of the breast. J Surg Case Rep (2019) 2019(1):rjy355. doi: 10.1093/jscr/rjy355

\section{FUNDING}

This study was supported by the National Natural Science Foundation of China (No.81872160). The above funders had no further role in the study design; collection, analysis, and interpretation of data; writing of the manuscript; or decision to submit this manuscript for publication.

\section{SUPPLEMENTARY MATERIAL}

The Supplementary Material for this article can be found online at: https://www.frontiersin.org/articles/10.3389/fonc.2021. 621012/full\#supplementary-material

16. Kasagawa T, Suzuki M, Doki T, Fujimori T, Itami M, Takenouchi T, et al. Two cases of adenoid cystic carcinoma: preoperative cytological findings were useful in determining treatment strategy. Breast Cancer (2006) 13(1):112-6. doi: $10.2325 /$ jbcs.13.112

17. Gupta RK, Dowle C. Fine-needle aspiration cytodiagnosis of adenoid cystic carcinoma of the breast. Diagn Cytopathol (1996) 14(4):328-30. doi: 10.1002/ (SICI)1097-0339(199605)14:4<328::AID-DC10>3.0.CO;2-M

18. Quinodoz IS, Berger SD, Schafer P, Remadi S. Adenoid cystic carcinoma of the breast: utility of immunocytochemical study with collagen IV on fine-needle aspiration. Diagn Cytopathol (1997) 16(5):442-5. doi: 10.1002/(sici)1097-0339 (199705) 16:5<442::aid-dc11>3.0.co;2-j

19. Gupta RK, Green C, Naran S, Lallu S, Fauck R, Dowle C, et al. Fine-needle aspiration cytology of adenoid cystic carcinoma of the breast. Diagn Cytopathol (1999) 20(2):82-4. doi: 10.1002/(sici)1097-0339(199902) 20:2<82::aid-dc8>3.0.co;2-0

20. Pandya AN, Shah P, Patel R, Patel PR. Adenoid cystic carcinoma of breast and the importance of differentiation from collagenous spherulosis by FNAC. J Cytol (2010) 27(2):69-70. doi: 10.4103/0970-9371.70748

21. Bhosale SJ, Kshirsagar AY, Patil RK, Wader JV, Nangare N, Patil PP. Adenoid cystic carcinoma of female breast: A case report. Int J Surg Case Rep (2013) 4 (5):480-2. doi: 10.1016/j.ijscr.2013.01.025

22. Ilkay TM, Gozde K, Ozgur S, Dilaver D. Diagnosis of adenoid cystic carcinoma of the breast using fine-needle aspiration cytology: A case report and review of the literature. Diagn Cytopathol (2015) 43(9):722-6. doi: $10.1002 /$ dc. 23272

23. Saqi A, Mercado CL, Hamele-Bena D. Adenoid cystic carcinoma of the breast diagnosed by fine-needle aspiration. Diagn Cytopathol (2004) 30(4):271-4. doi: $10.1002 /$ dc. 20015

24. Harish K, Mangala Gouri SR. Adenoid cystic carcinoma of the parotid metastasizing to liver: case report. BMC Cancer (2004) 4:41. doi: 10.1186/ 1471-2407-4-41

25. Sequeiros Santiago G, Rodrigo Tapia JP, Llorente Pendas JL, Suarez Nieto C. [Prognostic factors in adenoid cystic carcinoma of salivary glands]. Acta Otorrinolaringol Esp (2005) 56(8):361-7. doi: 10.1016/s0001-6519(05)78630-1

26. Vranic S, Bender R, Palazzo J, Gatalica Z. A review of adenoid cystic carcinoma of the breast with emphasis on its molecular and genetic characteristics. Hum Pathol (2013) 44(3):301-9. doi: 10.1016/ j.humpath.2012.01.002

27. Arpino G, Clark GM, Mohsin S, Bardou VJ, Elledge RM. Adenoid cystic carcinoma of the breast: molecular markers, treatment, and clinical outcome. Cancer (2002) 94(8):2119-27. doi: 10.1002/cncr.10455

28. Cavanzo FJ, Taylor HB. Adenoid cystic carcinoma of the breast. An analysis of 21 cases. Cancer (1969) 24(4):740-5. doi: 10.1002/1097-0142(196910) 24:4<740::aid-cncr2820240412>3.0.co;2-h

29. Sumpio BE, Jennings TA, Merino MJ, Sullivan PD. Adenoid cystic carcinoma of the breast. Data from the Connecticut Tumor Registry and a review of the literature. Ann Surg (1987) 205(3):295-301. doi: 10.1097/00000658198703000-00013

30. Millar BA, Kerba M, Youngson B, Lockwood GA, Liu FF. The potential role of breast conservation surgery and adjuvant breast radiation for adenoid cystic 
carcinoma of the breast. Breast Cancer Res Treat (2004) 87(3):225-32. doi: $10.1007 / \mathrm{s} 10549-004-8693-\mathrm{z}$

31. Youk JH, Kim MJ, Kim EK, Lee JY, Oh KK, Park BW. Recurrence of adenoid cystic carcinoma in the breast after lumpectomy and adjuvant therapy. J Ultrasound Med (2006) 25(7):921-4. doi: 10.7863/jum.2006. 25.7.921

32. Goldbach MM, Hoffman DI, Burkbauer L, Nayak A, Tchou J. Treatment Patterns and Clinical Outcomes of Adenoid Cystic Breast Carcinoma: A Single-Institution Experience. Am Surg (2020) 86(12):1684-90. doi: 10.1177/ 0003134820942287
Conflict of Interest: The authors declare that the research was conducted in the absence of any commercial or financial relationships that could be construed as a potential conflict of interest.

Copyright (๑) 2021 Zhang, Fang, Zhang and Wang. This is an open-access article distributed under the terms of the Creative Commons Attribution License (CC BY).

The use, distribution or reproduction in other forums is permitted, provided the original author(s) and the copyright owner(s) are credited and that the original publication in this journal is cited, in accordance with accepted academic practice. No use, distribution or reproduction is permitted which does not comply with these terms. 